\title{
An Analytical Study on Determining Effective Factors for Recruiting Right Person
}

\author{
Md. Sajedur Rahman, Md. Shajedul Islam
}

Lecturer, School of Business, University of Information Technology and Sciences, Rajshahi, BANGLADESH

\begin{abstract}
The general aim of this study is to evaluate and measure the effectiveness of recruitment and selection and its impact on service delivery amongst staff within the Development of Human Resource Policy. Research has shown that motivated and satisfied employees are more productive and that there is an improvement on service delivery. Factors, which influence employee motivation, are inter alia as efficient recruitment and selection methods, achievement, advancement, being treated with respect and personal growth and development. It is suggested that a possible way to succeed with recruitment and selection would be to gain their full co-operation with the aims and goals of the national objectives and the objectives of the department, to achieve, maintain and enhance the service delivery of staff, who are also potential future leaders in the organization. This should be coupled to a commitment to excellence and efficiency in the organization in general.
\end{abstract}

Key Words: Human resource planning, Job analysis, Recruitment, Selection

\section{INTRODUCTION}

Human resource is the most valuable asset to any organization who individually and collectively contributes to the achievement of the organizational goals and objectives. In the 21st century, there were increasing claims that the means to competitive advantage is achieved through human resource. In a situation where identical non-people resources in the form of finance, raw materials, plants, technology, hardware and software are made available to competing organizations differences in economic performance between organizations must be attributed to differences in the performance of human resource. In this regard, this article is geared towards analyzing the rational factors i.e. the importance and role of human resource planning and job analysis as a corporate activity that drives other human resource functions notably recruitment and selection process. Yet, as competition and technological innovations increase and product life cycles get shorter, jobs are becoming not only less static, but also less individually-based. Consequently, the tasks to be performed and the knowledge, skills and abilities (KSAs) required for effective job performance are also becoming more volatile and sometimes more team-based. Furthermore, and in all likelihood, organizations may perceive the creation of jobs that do not currently exist, the analysis of which is beyond the scope of traditional job analysis. Employee selection occurs after recruitment. Employees are selected based on their fit with the job qualifications, organizational culture and work team etc. As mentioned previously, the selection process must be compliant with Equal Employment Opportunity (EEO) regulations. A detailed 
job description also adds to the fairness of the selection process, as rejected applicants can interpret the minimum requirements needed and why they did not meet those criteria.

\section{Objectives of the Study}

- Finding effective contributory factors to recruitment and selection of potential employees for an organization.

- Evaluating impacts of biographical variables on recruitment and selection.

- Examining how job analysis, HR planning, recruitment and selection integrate with other HR functions.

\section{LITERATURE REVIEW OF THE STUdY}

Heneman and Judge, (2009) ${ }^{10}$ Observed that Job analysis is the process of studying jobs in order to gather, analyze, synthesize and report information about job requirements $\mathrm{A}$ job analysis provides a recruiter with a thorough understanding of the position, the essential functions of the job, a list of tasks or duties performed by the job and the knowledge, skills and abilities needed to perform the duties of the job.

According to De Cenzo and Robbins (2005:20) ${ }^{7}$ whenever the organization is engaged in a process of determining its human resource needs, it becomes involved in a process called Human Resource Planning. Human Resource Planning is one of the most important elements within a successful Human Resource Management Program, since it is a process by which the organization ensures that it has the right number and kinds of people, who are at the right place, at the right time, capable of effectively and efficiently completing those tasks that will help the organization to achieve its overall strategic objectives. Employment planning translates the organization's overall goals into the number and types of workers that are needed to meet those goals. Without clear-cut planning and direct linkage to the organization's strategic direction, estimations of an organization's human resource needs are reduced to mere guesswork. Employment planning cannot exist in isolation it must be linked to the organization's overall strategy.

Cole, (2002:102) ${ }^{5}$ state that the principal purpose of recruitment activities is to attract sufficient and suitable potential employees to apply for vacancies in the organization. The principal purpose of selection activities, by comparison, is to identify the most suitable applicants and persuade them to accept a position in the organization. The importance of having efficient and effective procedures for recruitment and selection can hardly be exaggerated.

Dowling, et al, (1999: 15) ${ }^{9}$, Recruitment is defined as a searching for and obtaining potential job candidates in sufficient numbers and quality so that the organization can select the most appropriate people to fill its job needs. Selection is the process of gathering information for the purposes of evaluating and deciding who would be employed in particular jobs. Various factors such as female mangers, dual-career couples, equal opportunity legislation, and expatriate failure that impact on multi-nationals ability to recruit and select high-caliber staff.

\section{Factors Affecting Recruitment and Selection Process}

Recruitment and selection process is affected by many environmental factors. There are many external and internal factors that affect recruitment and selection. The internal forces or factors are the factors that can be controlled by the organization. And the external factors are those factors which cannot be controlled by the organization. The controllable (internal) and uncontrollable (external) factors affecting recruitment and selection functions of an organization are: 


\section{Controllable Factors}

Every organization needs to analyze the controllable factors which help to effective recruitment are as follows:

Organizational Recruiting Policy: The recruitment policy of the firm affects the recruitment process. Organizations with a philosophy of developing their human resources and of providing opportunities for growth favor internal recruiting policies. Employees who desire the opportunity to advance in an organization generally prefer such a policy. Organizations with recruiting policies tend to spend relatively large sums on training and development programs so as to prepare employees for higher-level jobs.

Demographic Factors: Demography is the study of human population in terms of occupation, religion, age, sex, composition, ethnicity, etc. The demographic factors have profound influence on recruitment process.

Human Requirements: This includes information regarding the job's human requirements, such as job-related knowledge or skills (education, training, work experience) and required personal attributes (aptitudes, physical characteristics, personality, interest). Good health, pleasing manners, no significant disabilities in voice, hearing and eyesight, neat conventional dress, well groomed and takes trouble with details of personal appearance.

Interest: To justify really the candidate or applicant for the specific position is interested or not. Evidence of some interest outside work but nothing specific

Disposition: Acceptability to other people and previous occupational evidence of influencing others, ability to accept responsibility without undue strain and cooperative in relations with others.

Motivation: Ambitions- evidence of fairly rapid promotion and achievement of high but realistic goals; must be willing to control output to meet vigorous performance standards/targets.

Talent Pool: A company reaches into its local community to satisfy employment recruiting needs. If the local talent pool changes, then the company may find it more difficult to recruit qualified candidates. For example, if other businesses start to leave the region, then the availability of jobs drops and qualified candidates begin looking for work in other parts of the country. The company is then faced with decisions that involve paying to relocate new employees or opening new locations to access new talent pools.

Geography: Geography posses several issues for recruiting talent. Depend on the geographic suitability qualified candidates leaving the area or there not being enough candidates experienced in the fields the organization are hiring for, having a lack of local qualified candidates can be a problem.

Machines, Tools, Equipment and Work Aids: This category includes information regarding tools used, materials processed, knowledge dealt with or applied (such as finance or law), and services rendered (such as counseling or repairing).

Performance Standards: The employer may also want information about the job's performance standards (in terms of quantity or quality levels for each job duty, for instance). Management will use these standards to appraise employees.

Job Context: This includes information about such matters as physical working conditions, work schedule, and the organizational and social context-for instance, the number of people with whom the employee would normally interact. Information regarding incentives might also be included here.

Special Aptitudes: Fluency in speaking \& writing, Analytical skills, Ability to prepare and understand basic statistical information, competence in arithmetic, and high degree of listening skills. 
Outsourcing: The concept of outsourcing activities that are not a company's core competency is an internal business practice that affects recruiting.

Size of the Organization: Recruitment process is affected by the size of the organization to a large extent. Experience suggests that larger organizations recruit more candidates than small ones. Large organizations find recruitment less problematic than small organizations.

Working Conditions and Benefit Packages: These have strong influence on turnover and necessitate future recruiting. The rate of growth of organization- the phase in the life-cycle of the firm is a measure of the recruiting effort.

Cost and Time Constraints: Cost and time constraints pose obvious limitations on recruiting efforts. If an organization with very little money allocation for recruiting will not even consider hiring a right person for the right position.

Image of the Organization: Image or goodwill of the organization also affects the recruitment. Organizations having good image can attract potential and competent candidates to a large extent. Good public relation, rendering public services, etc. help to enhance the image and reputation of the organization.

Nature of Job: Jobs having good image in terms of better remuneration, working condition, promotion, career development opportunities etc. can attract the potential and qualified candidates to a large extent.

\section{Uncontrollable Factors}

The following discussion focuses on the factors those are not controlled by organizations.

Labor Market: Conditions of the labor market are a major factor in the design of the recruiting and selecting process. Labor market affects the size and quality of the applicant pool which in turn affects the choice of selection methods. Labor market constitutes the force of demand and supply of labor of particular importance. For instance, if demand for a particular skill is high relative to its supply, the recruitment process evolves more efforts. Contrary to it, if supply is more than demand, the recruitment process will be easier. Both scenarios influence the recruitment process and activities.

Government Policy and Legal Factors: Several laws have been passed that provide for equal employment opportunity (EEO). Bangladesh Labor Law-2006, prohibit employment practices that discriminate on the basis of race, color, religion, national origin, sex or age and so forth. Thus Equal employment legislation remains the most significant influence on the design of selection systems. Government policy plays an important role in the determination of recruitment practice.

Social, Cultural, and Political Environment: The forces of social, culture and political environment also influence recruitment policy. For instance, the change in government can have a direct impact upon recruitment policy of the company due to change in government rules and regulations.

Type of Labor to be Recruited: It is important to clearly specify recruiting goals in terms of number and type of labor to be recruited. The type of labor to be recruited affects the scope of the recruiting effort. Each type of labor has its own labor market. Generally, labor markets are smaller in number for labor types that are highly specialized or that require higher levels of education and experience.

Unemployment Situations: Unemployment rate of particular area is yet another influencing factor of recruitment process. If the unemployment rate is high, the recruitment process will be simpler and vice versa. 
Trade Unions: In some organizations unions are involved in the development of recruitment and selection policy and procedures. Trade Unions basically wants to pursue companies to enter into agreements that stipulate only union members will be employed.

Competition: Companies within the same industry are competing for qualified candidates to ensure future growth. In this purpose the organization need to analyze what their competitors offer new employees and try to develop a competitive package to tempt in the talent that the organization need.

\section{Challenges to Recruit Right Person}

An organization's business performance depends on having the right human resource capability to support the business needs and the recruitment and selection function is the first step in achieving this. Potential business risks are associated with performing this key strategic human resource strategy and these can emerge throughout the process from sourcing potential candidates through to the negotiation of the employment contract.

Costs to an organization from a financial and business performance perspective can be quite high if a poor selection is made. For example, poor selection decisions can result in absenteeism, employee turnover, work related accidents and higher training costs. A common problem in recruitment and selection is poor HR planning. Rigorous HR planning translates business strategies into specific HRM policies and practices. This is particularly so with recruitment and selection policies and practices. The key goal of HR planning is to get the right number of people with the right skills, experience and competencies in the right jobs at the right time at the right cost. Detailed and robust recruitment and selection policies, such as recruitment and selection procedures, assessing criteria, talents auditing and processing the information about the labor market are important in recruiting and deploying appropriate employees at the right time. Moreover, effective recruitment and selection is possible only if there is a dedicated and competent HR team.

\section{RECOMMENDATIONS}

Misleading communications regarding employment contract provisions can result in the loss of a desired candidate and potential claims for redress through industrial mechanisms. To minimize the risks organizations need to:

- Effectively conducting job analysis and targeting right potential candidates ensures a good match between applicants and the jobs.

- Design and implement credible and transparent recruitment and selection frameworks and processes;

- Ensure compliance with anti discrimination legislation throughout the process;

- Select assessment methods and tools appropriate for predicting the required performance outcome for the position;

- Select the most appropriate methods for sourcing potential candidates;

- Ensure that recruitment and selection policies and practices are strategically integrated with business.

The recruitment and selection function should also have measures in place to evaluate performance in relation to the time taken to fill vacancies; the costs associated with conducting the process internally/externally; and quality of candidate selection and retention. 


\section{CONCLUSION}

Selecting the right person for the right position is specifically important for the organization in nowadays. Inappropriate recruitment and selection not only waste organization's time and effort, but also diminish its profitability and impair it competitive advantage. Therefore, job analysis and human resource planning is vital and critical, not only for particular general recruitment and selection process, but also for the organization itself. Job analysis is specifically vital for organizational consistent competitive advantage. Sufficient job analysis enable organization to target on potential talents that with requisite knowledge, skills and abilities; once those talents are employed by the organization will inevitably add value to the organization, which is rare and inimitable. From organizational employers' perspective, good quality of job analysis assist targeting and attract potential recruits; whereas from the individual applicants' perspective, sufficient job analysis helps them to be more convenient to make up their mind about whether to apply for the job or not. Currently, due to various dynamic factors, such as restructured global market, updated policies and more diversified and flexible employment arrangement, all inevitably have important implication for each organization and its human resource management. With fully considering the changing nature of the environment, many scholars propose two general trends for job analysis future development. Technically, job analysis technique could be subcategorized into two groups, which are work-oriented and worker-oriented. The former focus on the various job related tasks; whereas the latter emphasizes more on broad human behaviors involved in work activities. Under current dynamic environment featured with changing nature of the job, worker-oriented seems more appropriate, which provides the organization's flexibility needs, and focus more on tasks and cross-function skills of workers.

\section{REFERENCES}

Ash. R. (1988). Job analysis in the world of work. In S. Gael (Ed.). The job Analysis Handbook/or Business. New York: john Wiley and Sons.

Brannick. M. T. \& L Evine. E. L (2002). Job analysis. Methods. Research and Applications for Human Resource Managementin the New MiHennium California: Sage Publications. Inc.

Catano. V. Cronshaw. S, Wiesner. W, Hackett, R \& Methot, L (1997). Recruitment and selection in Canada. Toronto: ITP Press.

Clifford. J. (1994). Job analysis: Why do it and how it should be done? Public Personnel Management.

Cole, E., (2002). Personnel and Human Resource Management. London YHT, Fifth Edition

Cushway, B. (2011). The employer's handbook: An essential guide to employment law: Personnel policies and procedures. Milford, CT: Kogan Page.

Decenzo, D.A. \& Robbins, S.P., (2005), Fundamentals of Human Resource Management. New York: John Wiley \& Sons, INC Eighth Edition

Dess, Gregory, G. and Jason, D. Shaw (2001), Voluntary turnover, social capital, and Organizational performance, Academy of Management Review.

Dowling, P.J., Welch, D.E., Schuler, R.S., (1999). International Human Resource Management. South Western Publishing

Heneman III H.G. and Judge T. A. (2009), Staffing organization (6 ${ }^{\text {th }}$ Edition), Boston M. A. McGraw-Hill Irwin

http://recruitment.naukrihub.com/factors-affecting-recruitment.html, retrieved on 23 June 2013

http:/ / smallbusiness.chron.com/internal-external-factors-influencing-recruitment-11905.html, retrieved on 25 June 2013 
http://wiki.answers.com/Q/What_are_some_factors_affecting_recruitment, retrieved on 27 June 2013

http://www.scribd.com/doc/43326700/25/Factors-Affecting-Recruitment, retrieved on 30 June 2013

Kaplan, R. S. \& Norton, David, P. (2004), Strategy Maps: Converting Intangible Assets into Tangible Outcomes, Harvard Business School Press, Boston, USA

Noe, R. A. (2012). Human resource management: Gaining a competitive advantage. New York, NY: McGraw-Hill.

Oswald. F. L (2003). Job Analysis: Methods, Research and applications for human resource management in the new millennium. Personnel Psychology.

Pilbeam. S \& Corbridge S, (2002), "People Resourcing HRM in Practice, 2/e, Pearson Education Ltd. UK.

Robertson, I T and Smith, M (2001), Personnel Selection, Journal of Occupational and Organizational Psychology

Siddique. C. M. (2004). Job Analysis: A strategic human resource management practice. International journal / Human Resource Management

Syrett, M. (2006), Four Reflections on Developing a Human Capital Measurement Capability, in what's the Future for Human Capital? CIPD, London.

Ulrich, D and Brockbank, W (2005). The HR Value Proposition, Harvard Press, Cambridge, MA.

Voskuijl, O. F. (2005). job Analysis: Current and future perspectives, In A. Evers, N. Anderson, \& O. Voskuijl (Eds.), The Blackwell Handbook of Personnel Selection Oxford: Blackwell Publishing.

Wernimont, P. (1988). Recruitment, selection and placement. In S. Gael (Ed.), The job analysis handbook for business, industry, and government, vol. 1. New York: john Wiley and Sons

Wrightt, P.M., Snell, S.A and Jacobson (2004) "Current Approaches to Human Resource Strategies Inside-out Versus Outside" in Human Resource Planning. 